\title{
Identification of Eimeria mitis and Eimeria praecox in Broiler Feces Using Polymerase Chain Reaction
}

Author(s)

Meireles $\mathrm{MV}^{1}$

Roberto $\mathrm{LO}^{2}$

Riera $\mathrm{RF}^{2}$

Assistant Professor - Avian Diseases Veterinary Medicine

UNESP - Campus de Araçatuba, SP, Brazil

2 Undergraduate student - Veterinary Medicine

\section{Mail Address}

Dr. Marcelo Vasconcelos Meireles

UNESP - Campus de Araçatuba

CP 341

Rua Clóvis Pestana, 793

Jd. Dona Amélia

16.050-680 - Araçatuba, SP, Brazil

E-mail: marcelo@fmva.unesp.br

\section{Keywords}

diagnosis, Eimeria mitis, Eimeria praecox, epidemiology, polymerase chain reaction.

\section{Acknowledgements}

This study was supported by Fundação de Amparo à Pesquisa do Estado de São Paulo (FAPESP) which provided grants (Proc. 00/ 09263-4) and scholarships to LOR and RFR (Proc. 00/14417-0 and 00/14418-7).

\section{ABSTRACT}

There are few reports concerning the epidemiology of Eimeria praecox and Eimeria mitis in Brazil. In the present experiment, the polymerase chain reaction (PCR) was used to identify these species in 156 samples of broiler chicken feces from several Brazilian states and the Federal District. Oocysts present in feces samples were purified by sodium chloride flotation followed by addition of DNAzol reagent (Invitrogen ${ }^{\circledR}$ ) for extraction of genomic DNA. DNA was precipitated and stored following DNAzol reagent manufacture's instructions. The primers and PCR conditions were as described by Schnitzler et al. (1999). In the 156 field samples analyzed by PCR, 70 and 45 were positive for $E$. praecox and $E$. mitis, respectively. In this study we have shown that DNA extraction using DNAzol followed by PCR can be a useful tool in epidemiological studies, since it provides fast and reliable detection of Eimeria sp. in field samples.

\section{INTRODUCTION}

Eimeriosis is the most important protozoan disease to the world poultry industry. In spite of some controversy (Shirley et al., 1983; Barta et al., 1997), domestic chickens are considered susceptible to seven species of Eimeria: E. acervulina, E. brunetti, E. maxima, E. mitis, E. necatrix, E. praecox and E. tenella.

The identification of Eimeria species is commonly accomplished through the analysis of some characteristics such as pre-patent period, morphology and morphometry of oocysts and other stages of the life cycle, site of development in the host, macroscopic lesions and isoenzyme analysis by electrophoresis (Joyner \& Long, 1974; Chapman, 1982).

The analysis of these characteristics is labor intensive to be used as routine diagnostic procedure and does not provide enough data for identification to the species level. Oocysts morphology and morphometry may differ a little within a specie. In addition, characteristics may be similar among different species. The analysis of macroscopic lesions and parasite site of development in the host requires the availability of birds for necropsy and generally does not provide conclusive data, mainly in infections caused by E. mitis and E. praecox.

Pre-patent period data may be used for E. praecox identification, but the procedure demands birds and facilities for experimental inoculation. Furthermore, this characteristic must be cautiously interpreted due to the introduction of precocious vaccine strains with shorter pre-patent period in broiler flocks (Shirley \& Bedrnik, 1997).

Isoenzyme analysis can also be used for identification of Eimeria species. This technique is efficient but laborious, demands a great number of oocysts and is not conclusive for all field isolates (Chapman, 1982; Kucera, 1990). 
Schnitzler et al. (1998) and Schnitzler et al. (1999) designed species-specific primers to be used in the polymerase chain reaction (PCR) to identify the seven Eimeria species of domestic chickens.

There are few reports related to the occurrence of the less pathogenic Eimeria species of domestic chickens, such as E. mitis and E. praecox, mainly in Brazil (Kawazoe \& Figueiredo, 1990; Santos et al., 2003). Despite the current belief that these species have low pathogenicity, they can be responsible for decreased weight gain, poorer feed efficiency and shank pigmentation in broiler chickens (Gore \& Long, 1982; Ruff \& Edgar, 1982; Fitz-Coy \& Edgar, 1992; Jorgensen et al., 1997).

Owing to the lack of information related to domestic chicken eimeriosis in Brazil and to its recognized economic importance to the poultry industry, this work was carried out to determine whether $E$. mitis and $E$. praecox are present in some Brazilian states and the Federal District through the utilization of PCR, a highly sensitive and specific technique.

\section{MATERIAL AND METHODS}

\section{Samples}

One hundred and fifty six samples of feces were collected from broiler chickens as follows: 18 samples from the Federal District, 24 from Goiás State, 23 from Mato Grosso do Sul, 2 from Minas Gerais, 21 from Paraná, 42 from Rio Grande do Sul, 5 from Santa Catarina and 21 from São Paulo.

Each sample was a pool of many feces samples taken at different locations at one or more poultry houses belonging to one broiler integration and preserved in $2.5 \%$ potassium dichromate at $+4^{\circ} \mathrm{C}$.

DNA extracted from oocysts of $E$. mitis and $E$. praecox from the Czech Republic were kindly supplied by Dr. Petr Bedrník (Biopharm) and Prof. Arthur Gruber (São Paulo State University) and used as positive control. Ultra-pure autoclaved water served as negative control.

\section{Genomic DNA Extraction}

Oocysts present in $10 \mathrm{~g}$ of feces were purified in saturated saline solution and washed by centrifugation at $1,000 \times \mathrm{g}$ for $5 \mathrm{~min}$ with distilled water. The sediment containing oocysts was resuspended in phosphated buffered saline (PBS) pH 7.4 added with $0.1 \%$ Tween 80 , homogenized by vortexing and centrifuged at 800 $x \mathrm{~g}$ for $5 \mathrm{~min}$. Sodium hypochlorite 5-6\% was added and after 20 minutes at $4^{\circ} \mathrm{C}$ (Fernando \& Pasternak,
1991; Procunier et al., 1993), the sediment was washed with distilled water 4 times by centrifugation at $800 \mathrm{x}$ $\mathrm{g}$ for $5 \mathrm{~min}$.

One $\mathrm{mL}$ of DNAzol reagent (Invitrogen ${ }^{\circledR}$ ) was added to the sediment containing oocyst, transferred to a 1.5 $\mathrm{ml}$ microcentrifuge tube with 0.5 volume of $2-\mathrm{mm}$ glass beads, and vortexed continuously for 10 minutes at maximum speed. The tubes were centrifuged for 10 $\min$ at $10,000 \times g$ and the supernatant was transferred to a fresh $1.5-\mathrm{ml}$ microcentrifuge tube. The DNA was precipitated by adding 0.5 volume of $100 \%$ cold ethanol and mixing by inversion. The tubes were centrifuged at 4,000 $\times \mathrm{g}$ for $3 \mathrm{~min}$ and the supernatant was discarded. The DNA pellet was washed twice with $1 \mathrm{~mL}$ of $70 \%$ cold ethanol, mixed by inversion and centrifuged at $4,000 \times \mathrm{g}$ for $3 \mathrm{~min}$ at $4{ }^{\circ} \mathrm{C}$. The supernatant was discarded and the DNA sediment was eluted with $50 \mathrm{~mL} \mathrm{NaOH} 8 \mathrm{mM}$ and $5.05 \mathrm{~mL}$ of $0.1 \mathrm{M}$ HEPES buffer. Extracted DNA was purified using PrepA Gene DNA purification system (Bio-Rad ${ }^{\circledR}$ ) and stored at $-20^{\circ} \mathrm{C}$.

\section{Polymerase Chain Reaction (PCR)}

Samples were analyzed by PCR with the primers designed by Schnitzler et al. (1999) (Table 1).

The amplification reaction mixture consisted of 10 $\mathrm{mM}$ Tris- $\mathrm{HCl}(\mathrm{pH} 8.3), 50 \mathrm{mM} \mathrm{KCl}, 2 \mathrm{mM} \mathrm{MgCl}, 200$ $\mathrm{mM}$ of each deoxynucleoside triphosphate (dNTP), 10 pmol of each primer, $1 \mathrm{U}$ of platinum Taq DNA polymerase (Invitrogen ${ }^{\circledR}$ ) and $10 \mu \mathrm{L}$ of target DNA in a $50 \mathrm{~mL}$ reaction volume.

PCR cycling conditions were: denaturation at $95^{\circ} \mathrm{C}$ for $2 \mathrm{~min}$, followed by 29 cycles at $95^{\circ} \mathrm{C}$ for $30 \mathrm{~s}, 55^{\circ} \mathrm{C}$ for $30 \mathrm{~s}$, and $72^{\circ} \mathrm{C}$ for $60 \mathrm{~s}$ and a last extension step at $72^{\circ} \mathrm{C}$ for $7 \mathrm{~min}$. Amplifications were carried out in 0.2 $\mathrm{mL}$ polypropylene tubes using a MJ Research ${ }^{\circledR}$ PTC 100 termocycler. Ten $\mu \mathrm{L}$ of the amplified products were analyzed by electrophoresis on a $1.5 \%$ agarose gel stained with ethidium bromide and examined under UV light.

\section{Determination of PCR Sensitivity}

PCR sensitivity was determined using serial dilutions of suspensions containing 100,500, 1,000, 5,000, $10,000,25,000,50,000$ and 100,000 oocysts of $E$. mitis or $E$. praecox. The suspension corresponding to each dilution was spiked in one sample of $10 \mathrm{~g}$ of feces of chickens free of infection with Eimeria spp. Inoculated feces were homogenized and submitted to oocyst purification and DNA extraction as described above, followed by PCR for each dilution, in order to determine 


\begin{tabular}{|c|c|c|c|c|}
\hline Primer & Species & Sequence $\left(5^{\prime}-3^{\prime}\right)$ & Annealing position* & Amplification product size \\
\hline EPF & E. praecox & CATCATCGGAATGGCTTTTTGA & $151 \mathrm{bp}$ & 391 bp \\
\hline EPR & E. praecox & AATAAATAGCGCAAAATTAAGCA & $541 \mathrm{bp}$ & \\
\hline EmiF & E. mitis & TATTTCCTGTCGTCGTCTCGC & $158 \mathrm{bp}$ & 327 bp \\
\hline EmiR & E. mitis & GTATGCAAGAGAGAATCGGGA & $484 \mathrm{bp}$ & \\
\hline
\end{tabular}

the minimum detectable oocyst number. Feces samples were collected from birds reared in an isolator with positive pressure $\left(\mathrm{ALESCO}^{\circledR}\right)$ since the first day of life and were shown to be negative for Eimeriaspp. oocysts by flotation in saturated saline solution and PCR.

\section{RESULTS AND DISCUSSION}

The primers used (Schnitzler et al., 1999) amplified as expected species-specific DNA bands of 327 bp for E. mitis and 391 bp for E. praecox (Figure 1).

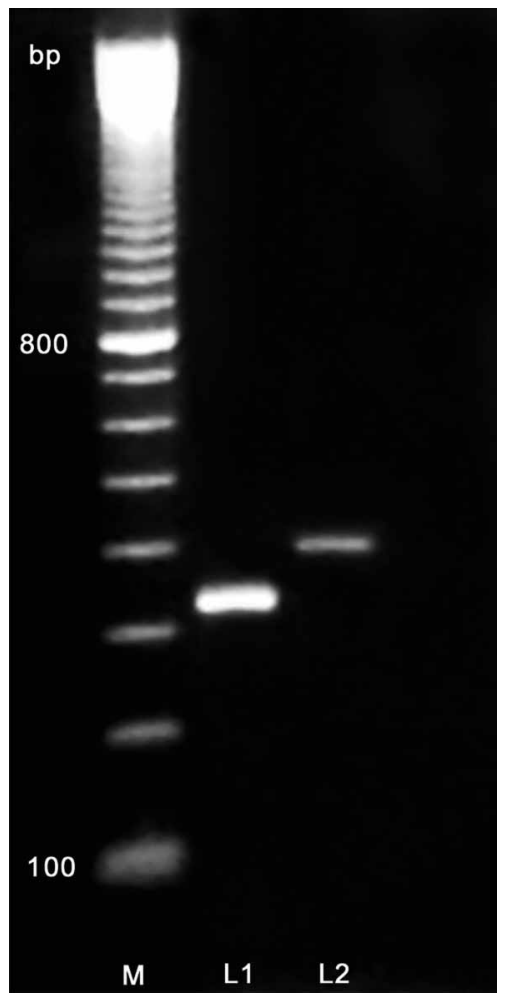

Figure 1 - Agarose gel electrophoresis. Polymerase Chain Reaction for E. mitis and E. praecox. M: 100 bp molecular weight marker; L1: Positive sample for E. mitis (327 bp). L2: Positive sample for E. praecox (391 bp).

The sensitivity of PCR was determined by spiking increasing oocyst numbers of $E$. mitis or $E$. praecox in the feces of birds free of Eimeria spp. infection. For both species, amplification of a specie-specific DNA band was observed in samples spiked with a minimum of 50 oocysts per gram of feces.

The analysis of 156 samples of feces collected in the different states showed that both species were present in almost every state, but $E$. mitis could not be detected in the states of GO and MG (Table 2). No DNA amplification band was observed in the negative controls, demonstrating absence of contamination in the PCR assay.

Table 2 - Results of Polymerase Chain Reaction for E. praecox and $E$. mitis in feces samples $(n=156)$ collected from broiler chickens in the different Brazilian States and the Federal District.

\begin{tabular}{|lcccccccccr} 
& & DF & GO & MG & MS & PR & RS & SC & SP Total \\
\hline E. mitis & Positive & 1 & 0 & 0 & 8 & 7 & 16 & 5 & 8 & 45 \\
& Negative17 & 24 & 2 & 15 & 14 & 26 & 0 & 13 & 111 \\
& & & & & & & & & \\
E. praecox & Positive & 7 & 6 & 1 & 12 & 11 & 18 & 4 & 11 & 70 \\
\hline & Negative11 & 18 & 1 & 11 & 10 & 24 & 1 & 10 & 86 \\
\hline
\end{tabular}

In Brazil, studies regarding avian eimeriosis epidemiology have already been carried out in the State of São Paulo, but with a restricted number of samples. The occurrence of E. mitis and E. praecox was detected in these reports (Kawazoe \& Figueiredo, 1990; Santos et al., 2003). In the present experiment, E. mitis was detected in five out of seven Brazilian states, besides the Federal District. A high occurrence of $E$. praecox was also observed in most samples.

The identification of Eimeria species in birds by PCR has the advantages of greater specificity and sensitivity in comparison to the conventional identification techniques (Lew et al., 2003). Recently, the simultaneous identification of 7 species of Eimeria using a multiplex PCR was reported in Brazil (Fernandez et al., 2003).

PCR is commonly used for the identification of Eimeria sp. in samples purified and containing a great amount of oocysts. This is the first report of 
determination of sensitivity of this technique and its use for identification of avian Eimeria species in field samples, in which the number of oocysts is generally small and therefore, makes diagnosis by the use of conventional techniques difficult and sometimes unviable.

It is worth noting that, in spite of the high sensitivity of $P C R$, the occurrence of false-negative results is possible, since in the conditions of the present study at least 50 oocysts per gram of feces were necessary to obtain positive results. It was also observed in this experiment that PCR coupled to DNA extraction directly from feces using DNAzol requires a posterior DNA purification to avoid the occurrence of false-negative results due to presence of $P C R$ inhibitory substances in the feces (Lawson et al., 1997).

The available information on avian eimeriosis are related to the species of Eimeria that cause more evident macroscopic lesions or are more economically relevant, as E. acervulina, E. brunetti, E. maxima, E. necatrix and $E$. tenella.

The presence of E. mitis and E. praecox in broiler flocks in several states demonstrates the need of including these two species in studies involving the economic impact of Eimeriasp. infection in the Brazilian poultry industry.

\section{REFERENCES}

Barta JR, Martin ED, Liberator PA, Dashkevicz M, Anderson JW, Feighner SD, Elbrecht A, Perkins-Barow A, Jenkins MC, Danforth $H D$, Ruff MD, Profous-Juchelka H. Phylogenetic relationships among eight Eimeria species infecting domestic fowl inferred using complete small subunit ribosomal DNA sequences. Journal of Parasitology 1997; 83:262-271.

Chapman HD. The use of enzyme electrophoresis for the identification of the species of Eimeria present in field isolates of coccidia. Parasitology 1982; 85:437-442.

Fernandez S, Pagotto AH, Furtado MM, Katsuyama AM, Madeira AM, Gruber A. A multiplex PCR assay for the simultaneous detection and discrimination of the seven Eimeria species that infect domestic fowl. Parasitology 2003; 127:317-325.

Fernando MA, Pasternak JJ. Eimeria spp. of the domestic fowl: resolution of chromosomes by field inversion gel electrophoresis. Experimental Parasitology 1991; 72:306-310.

Fitz-Coy SH, Edgar SA. Pathogenicity and control of Eimeria mitis infections in broiler chickens. Avian Diseases 1992; 36:44-48.

Gore TC, Long PL. The biology and pathogenicity of a recent field isolate of Eimeria praecox Johnson, 1930. Journal of Protozoology $1982 ; 29: 82-85$
Jorgensen WK, Stewart NP, Jeston PJ, Molloy JB, Blight GW, Dalgliesh RJ. Isolation and pathogenicity of Australian strains of Eimeria praecox and Eimeria mitis. Australian Veterinary Journal $1997 ; 75: 592-595$

Joyner LP, Long P. The specific characters of the Eimeria, with special reference to the coccidian of the fowl. Avian Pathology 1974; 3 : 145-157.

Kawazoe U, Figueiredo AC. Levantamento de coccidiose aviária em três granjas de frangos de corte da região de Campinas - São Paulo - Brasil. Arquivos Brasileiros de Medicina Veterinária e Zootecnia 1990; 42:317-336.

Kucera J. Identification of Eimeria species in Czechoslovakia. Avian Pathology 1990; 19:59-66.

Lawson AJ, Linton D, Stanley J, Owen RJ. Polymerase chain reaction detection and speciation of Campylobacter upsaliensis and C. helveticus in human faeces and comparison with culture techniques. Journal of Applied Microbiology 1997; 83:375-380.

Lew AE, Anderson GR, Minchin CM, Jeston PJ, Jorgensen WK. Interand intra-strain variation and PCR detection of the internal transcribed spacer 1 (ITS-1) sequences of Australian isolates of Eimeria species from chickens. Veterinary Parasitology 2003; 112: 33-50.

Procunier JD, Fernando MA, Barta JR. Species and strain differentiation of Eimeria spp. of the domestic fowl using DNA polymorphisms amplified by arbitrary primers. Parasitology Research 1993; 79:98-102.

Ruff MD, Edgar SA. Reduced intestinal absorption in broilers during Eimeria mitis infection. American Journal of Veterinary Research 1982; 43:507-509.

Santos RFS, Kavavata GM, Almeida SM, Hisano M, Calixto LFL, Meireles MV. Ocorrência de Eimeria sp. em frangos de corte no Estado de São Paulo. Ars Veterinaria 2003; 19:230-234.

Shirley MW, Bedrnik P. Live attenuated vaccines against avian coccidiosis: success with precocious and egg-adapted lines of Eimeria. Parasitology Today 1997; 13:481-484.

Shirley MW, Jeffers TK, Long PL. Studies to determine the taxonomic status of Eimeria mitis, Tyzzer 1929 and E. mivati, Edgar and Seibold 1964. Parasitology 1983; 87:185-198.

Schnitzler BE, Thebo PL, Mattsson JG, Tomley FM, Shirley MW. Development of a diagnostic PCR assay for the detection and discrimination of four pathogenic Eimeria species of the chicken. Avian Pathology 1998; 27:490-497.

Schnitzler BE, Thebo PL, Tomley FM, Uggala A, Shirley MW. PCR identification of chicken Eimeria: a simplified read-out. Avian Pathology 1999; 28:89-93. 